\title{
Association between Apoc4 allele and cardio- metabolic and social risk factors with cognitive impairment in elderly population from Bogota
}

\author{
Olga Lucia Pedraza ${ }^{1,2} \odot$, Isis Camacho ${ }^{1,2} \odot$, Fabio Alexander Sierra ${ }^{1,3} \bullet$, Rubio-Gómez Cladelis ${ }^{4}$, \\ Ana Maria Salazar ${ }^{1,25}{ }^{\bullet}$, Maria Camila Montalvo ${ }^{1,2} \odot$, Hector Daniel Morill $0^{6}{ }^{\circ}$, Angela Lozano ${ }^{1,2} \odot$, \\ Luz Dary Gutiérrez-Castañeda ${ }^{4}{ }^{\bullet}$, Lilian Torres-Tobar ${ }^{4}$, Cesar Piñeros $^{3 \odot}$
}

\begin{abstract}
Being an $\varepsilon 4$ carrier in the Apo $\varepsilon$ gene has been suggested as a modifying factor for the interaction between cardiometabolic, social risk factors, and the development of cognitive impairment. Objective: The main objective of this study was to assess the existence of such interaction in a sample of Bogota's elderly population. Methods: A cross-sectional study was conducted with 1,263 subjects older than 50 years. Each participant was diagnosed by consensus, after neuropsychological and neuropsychiatric evaluations, under a diagnosis of normal cognition, mild cognitive impairment (MCl) according to Petersen's criteria, or dementia according to DSM-IV criteria. Apo $\varepsilon$ was typified and an analysis of MoCA test was performed in each group carrying or not $\varepsilon 4$ allele. Results: Our study showed that $75 \%$ were women with a median age of 68 years (interquartile range 62-74 years) and a median schooling for 6 years (interquartile range 4-12 years). Dementia was related to low education level of $\leq 5$ years $\mathrm{OR}=11.20(95 \% \mathrm{Cl} 4.99-25.12)$, high blood pressure (HBP) $\mathrm{OR}=1.45(95 \% \mathrm{Cl} 1.03-2.05)$, and age over 70 years $\mathrm{OR}=7.68(95 \% \mathrm{Cl} 3.49-16.90)$, independently of being or not an $\varepsilon 4$ allele carrier. Diabetic subjects with dementia carrying $\varepsilon 4$ allele showed a tendency to exhibit lower scores on the MoCA test, when compared with noncarriers' diabetic subjects with dementia. Conclusions: The presence of $\varepsilon 4$ allele does not modify the relationship between cognitive impairment and the different cardio-metabolic and social risk factors, except in diabetic subjects $\varepsilon 4$ carriers with dementia who showed a tendency to exhibit lower scores of the MoCA test, when compared with noncarriers' diabetic subjects with dementia.
\end{abstract}

Keywords: Apoe4 allele, mild-cognitive impairment, dementia, MoCA test, educational status, cardiometabolic risk factors.

\begin{abstract}
ASSOCIAÇÃO ENTRE O ALELO APOE4, FATORES DE RISCO CARDIOMETABÓLICOS ESOCIAIS COM PREJUIZZO COGNITIVOEM IDOSOS DE BOGOTÁ
RESUMO. Ser um portador $\varepsilon 4$ no gene Apo $\varepsilon$ tem sido sugerido como um fator modificador da interação entre fatores cardiometabólicos, de risco social e o desenvolvimento de comprometimento cognitivo. Objetivo: 0 objetivo principal deste trabalho é avaliar a existência de tal interação em uma amostra da população idosa de Bogotá. Métodos: Um estudo transversal foi realizado com 1.263 indivíduos com mais de 50 anos. Cada participante foi diagnosticado por consenso após avaliações neuropsicológicas e neuropsiquiátricas, sob um diagnóstico de cognição normal, comprometimento cognitivo leve de acordo com os critérios de Petersen ou demência de acordo com os critérios do Manual Diagnóstico e Estatístico de Trastornos Mentais (DSM-IV). Apoe4 foi tipificada e uma análise do Montréal Cognitive Assessment Test (teste de MoCA) foi realizada em cada grupo portador ou não do alelo $\varepsilon 4$. Resultados: Nosso estudo mostrou que $75 \%$ eram mulheres com idade mediana de 68 anos (intervalo interquartil 62 a 74 anos) e escolaridade mediana de seis anos (intervalo interquartil 4 a 12 anos). A demência estava relacionada ao baixo nível de escolaridade $\leq 5$ anos Odds Ratio $(\mathrm{OR})=11,20$ (intervalo de confiança — IC95\% 4,99-25,12), pressão alta OR=1,45 (IC95\% 1,03-2,05) e idade acima de 70 anos OR=7,68 (IC95\% 3,49-16,90), independentemente de ser ou não portador do alelo $\varepsilon 4$. Indivíduos diabéticos com demência portadores do alelo $\varepsilon 4$ mostraram tendência de exibir pontuações mais baixas no teste MoCA quando comparados com indivíduos diabéticos com demência não portadores do alelo $\varepsilon 4$. Conclusões: A presença do alelo $\varepsilon 4$ não modifica a relação entre 0 comprometimento cognitivo e os diferentes fatores de risco cardiometabólico e social, exceto em diabéticos portadores de $\varepsilon 4$ com demência, que exibiram tendência a apresentar menores escores no teste MoCA quando comparados com indivíduos diabéticos com demência não portadores do alelo $\varepsilon 4$.
\end{abstract}

Palavras-chave: Apoє4, comprometimento cognitivo leve, demência, teste MoCA, escolaridade, fatores de risco cardiometabólico.

This study was conducted by the Fundacion Universitaria de Ciencias de la Salud, Bogotá, Colombia

${ }^{1}$ Neurosciences Group, Fundacion Universitaria de Ciencias de la Salud - Bogotá, Colombia. nterdisciplinary Memory Group, Hospital Infantil Universitario de San Jose - Bogotá, Colombia. ${ }^{3}$ Epidemiology and Biostatistics Research Group, Fundacion Universitaria de Ciencias de la Salud - Bogotá, Colombia. ${ }^{4}$ Basic Health Science Group, Fundacion Universitaria de Ciencias de la Salud - Bogotá, Colombia. ${ }^{5}$ Psychology, Cognitive Processes and Education Group, Universidad El Bosque - Bogotá, Colombia. ${ }^{6}$ Medicine Faculty, Fundacion Universitaria de Ciencias de la Salud - Bogotá, Colombia

Olga Lucia Pedraza. Medicine Faculty, FUCS, Av Suba \# 115-54 Torre A Consultorio 311. E-mail: opedraza@hospitalinfantildesanjose.org.co

Disclosure: The authors report no conflicts of interest.

Funding: This project received a grant from the Fundacion Universitaria de Ciencias de la Salud and the El Bosque University.

Received on December 12, 2020. Accepted in final on May 07, 2021. 


\section{INTRODUCTION}

$\mathrm{D}$ ementia has become an epidemic, because of the alarmingly worldwide elderly population increase, but with a modest benefit derived from therapeutic advances. ${ }^{1-3}$ Thus, the strategies to prevent and control risk factors have been outlined as useful therapeutic options in the control and evolution of this pathology. ${ }^{4}$

An association between modifiable and nonmodifiable risk factors has been suggested, which has allowed a better understanding of the intervention as an overriding mechanism of prevention. ${ }^{5}$ The main risk factors described for Alzheimer's dementia (AD), the most frequent dementia, are age, low schooling, cardiovascular and metabolic diseases (e.g., high blood pressure (HBP) and diabetes), genetic and inherited factors, and some lifestyles. ${ }^{6-10}$

Norton et al. described an increased relative risk (RR) for dementia with the presence of HBP and diabetes between 1.61 and 1.46, respectively, ${ }^{7}$ whereas in other studies, low schooling was related to the appearance of dementia in 1 of 5 subjects. ${ }^{10}$

Meanwhile, Riedel et al. ${ }^{11}$ and Santos et al. ${ }^{12}$ described that carrying the $\varepsilon 4$ allele in the Apoe gene was the main genetic risk factor related to the development of $\mathrm{AD}$. Other studies of clinical-genetic correlation showed that $\varepsilon 4$ allele carriers have a 10-fold higher risk of late sporadic $\mathrm{AD}$ if they are homozygous, or 2-3-fold higher risk if they are heterozygous. ${ }^{13}$ In the last years, some studies have postulated a possible interaction between genetic and cardio-metabolic risk factors, which would contribute to the development of cognitive impairment, considering that the $\varepsilon 4$ allele of the apolipoprotein $\mathrm{E}$ gene is a risk factor common for dementia and cardiovascular disease. ${ }^{8}$

Some authors also observed that the presence of vascular risk factors such as HBP combined with the presence of $\varepsilon 4$ allele would increase the possibility of presenting cognitive impairment. ${ }^{14-16}$ Zou et al. ${ }^{17}$ and Yamazaki et al. ${ }^{18}$ reported that diabetic subjects and $\varepsilon 4$ allele carriers had a higher prevalence of AD $(7.55 \%)$ as compared to diabetic non- $\varepsilon 4$ carriers ( $2.3 \%$ ), and concluded that diabetic $\varepsilon 4$ carriers' subjects would have a 3,982 [95\%CI 1,418-11,184] greater probability of developing dementia as compared to diabetic $\varepsilon 4$ noncarriers. ${ }^{17}$

Regarding the presence of social risk factors (age or low schooling), being an $\varepsilon 4$ carrier was related to the development of cognitive impairment according to the study made by Qian et al. ${ }^{19}$ and Kivipelto et al. ${ }^{20}$

For the above, we aimed to evaluate the association between cognitive impairment, being an $\varepsilon 4$ carrier and having a social, cardiovascular, or metabolic risk factor in a sample of elderly population from the city of Bogota.

\section{METHODS}

This study is part of the analysis of risk factors made in the study about cognitive impairment in adults from Bogotá, in which 1,263 autonomous adult subjects were invited to participate with a family member. Subjects who attended the invitation received an explanation of the study and those who agreed to participate were cited with their respective family member or companion. ${ }^{9}$

The inclusion criteria of the study were being 50 years of age or older, being autonomous living in community, and resident in Bogota without previous cognitive evaluation. Subjects with neuro-psychiatric illness history, illiterate, blind, deaf, and institutionalized were excluded from the study.

\section{Procedure}

After signing the informed consent, socio-demographic, health, and cardiovascular risk questionnaires were applied to each participant as well as a neuropsychological and neuropsychiatric assessment in two phases and each one was diagnosed by consensus, under a diagnosis of normal cognition, $\mathrm{MCI}$ according to Petersen's criteria, or dementia according to DSM-IV criteria. Subjects with the last two diagnoses were referred to their medical service. ${ }^{21,22}$

Body mass index (BMI) was calculated using measures of weight and height, and for the genotyping of ApoE, a blood sample was taken, and subsequently DNA extraction was performed. ${ }^{23,24}$

\section{Statistical analysis}

Central tendency and dispersion measures were used to describe quantitative variables, and absolute and relative frequencies to describe qualitative variables.

The MoCA-test score was compared among patients with and without risk factors, within each group of patients, $\varepsilon 4$ carriers and noncarriers using Mann-Whitney $U$ test, given that the distribution of this variable was not normal. Also, when statistical significance was reached, a non-parametric effect size, using Cliff's Delta, was calculated (<0.147 "negligible," <0.33 "small," $<0.474$ "medium," otherwise "large." ${ }^{25}$ A possible relationship between cognitive impairment, risk factors, and being or not $\varepsilon 4$ allele carrier was explored through a multiple correspondence analysis: the illustrative variable was being or not $\varepsilon 4$ carrier and the active variables were risk factors and cognitive group.

Subsequently, a regression analysis was applied using the MoCA-test score as the dependent variable and as independent variable the interaction between the APOE ( $\varepsilon 4$ carriers versus noncarriers) and the risk factors (diabetes, HBP, dyslipidemia, overweight, low schooling, and age over 70 years), adjusting the data obtained for 
each cognitive group (normal, MCI and dementia) by age. A non-parametric quantile regression was used, considering that MoCA-test score did not follow a normal distribution. The risk factor, low schooling, was analyzed in two ways: as five or less years or as ten or less years of schooling, which correspond in our context to primary or incomplete bachelor, respectively. High schooling were high-school graduates, technicians, and university students. Statistical analysis was performed using the $\mathrm{R}$ (libraries FactoMineR and effsize) and Stata $13^{\circledR}$ programs. Significance was assessed at $\mathrm{p}<0.05$ corrected for multiple comparisons using the Boferroni correction.

\section{Ethics}

This study was approved by the FUCS Human Research Ethics Committee and complies with the requirements of the Helsinki Declaration and Resolution 8430 of 1993 on research with human beings in Colombia.

\section{RESULTS}

For this analysis, 1,214 subjects who had complete data on the risk factors assessed diabetes mellitus (DM), HBP, dyslipidemia, overweight, low schooling, and age over 70 years and APOE genotyping were included.

Approximately $75 \%$ were women with a median age of 68 years (interquartile range [IQR]) age 62 and 74 years and a median schooling for 6 years (IQR) 4 to 12 years; $43.5 \%$ of the participants were cognitively normal, 34.1\% had MCI, and 22.4\% dementia (Table 1).

The frequency of our APOE genotype, previously described, was distributed as follows: $\varepsilon 3 / \varepsilon 373.4 \%, \varepsilon 3 /$

Table 1. Absolute and relative frequency of sociodemographic characteristics, and vascular and metabolic risk factors according to cognitive status.

\begin{tabular}{|c|c|c|c|c|}
\hline \multirow[b]{2}{*}{ Characteristics } & \multicolumn{3}{|c|}{ Cognition } & \multirow{2}{*}{$\begin{array}{l}\text { Total } \\
1,214\end{array}$} \\
\hline & $\begin{array}{c}\text { Normal } \\
528(43.5 \%)\end{array}$ & $\begin{array}{c}\text { MCI } \\
414(34.1 \%)\end{array}$ & $\begin{array}{c}\text { Dementia } \\
272(22.4 \%)\end{array}$ & \\
\hline \multicolumn{5}{|l|}{ Sociodemographic features } \\
\hline Female gender & $384(72.7)$ & $313(75.6)$ & $217(79.8)$ & $914(75.3)$ \\
\hline Age-median (IQR) & $64(60-70)$ & $70(64-74)$ & $73(66-79)$ & $68(62-74)$ \\
\hline \multicolumn{5}{|l|}{ Age in categories } \\
\hline $50-59$ years & $123(23.3)$ & $48(11.6)$ & $12(4.4)$ & $183(15.1)$ \\
\hline $60-69$ years & $264(50)$ & $158(38.2)$ & 87 (31.9) & 509 (41.9) \\
\hline$\geq 70$ years & $141(26.7)$ & $208(50.2)$ & $173(63.6)$ & $522(43.0)$ \\
\hline Schooling-median (IQR) & $11(5-17)$ & $5(3-11)$ & $4(2-5)$ & $6(4-12)$ \\
\hline \multicolumn{5}{|l|}{ Schooling in categories } \\
\hline 0 a 5 years & $147(27.8)$ & $211(50.9)$ & $217(79.8)$ & $575(47.4)$ \\
\hline 6 a 10years & $76(14.4)$ & $82(19.8)$ & $30(11.0)$ & $188(15.5)$ \\
\hline$\geq 11$ years & $305(57.8)$ & $121(29.3)$ & $25(9.2)$ & $451(37.2)$ \\
\hline \multicolumn{5}{|l|}{ Body mass index } \\
\hline$<26$ & $228(43.2)$ & $177(42.8)$ & $101(37.1)$ & $506(41.7)$ \\
\hline $26-29$ & $190(35.9)$ & $136(32.9)$ & $99(36.4)$ & $425(35.0)$ \\
\hline$\geq 30$ & $110(20.8)$ & $101(24.4)$ & $72(26.5)$ & $283(23.3)$ \\
\hline \multicolumn{5}{|c|}{ Vascular and metabolic risk factors } \\
\hline DM & $63(11.9)$ & $59(14.3)$ & $45(16.5)$ & 167 (13.8) \\
\hline HBP & $212(40.2)$ & $195(47.1)$ & $163(59.9)$ & $570(46.9)$ \\
\hline Overweight & $300(56.8)$ & $237(57.3)$ & $171(62.9)$ & $708(58.3)$ \\
\hline Dyslipidemia & $167(31.6)$ & $153(36.9)$ & 86 (31.6) & 406 (33.4) \\
\hline
\end{tabular}

DM: diabetes mellitus, HBP: high blood pressure; MCl: mild cognitive impairment. Values are expressed as absolute numbers and percentages of the study population in parenthesis. 
$\varepsilon 420.2 \%, \varepsilon 2 / \varepsilon 34.4 \%, \varepsilon 4 / \varepsilon 41.4 \%, \varepsilon 2 / \varepsilon 40.4 \%$, and $\varepsilon 2 /$ $\varepsilon 20.08 \%$. A total of $22 \%$ of participants were carriers of the $\varepsilon 4$ allele, being $1.5 \%$ with homozygous genotype and $20.6 \%$ heterozygous. Allelic frequency was $\varepsilon 385.5 \%, \varepsilon 4$ $11.9 \%$, and $\varepsilon 22.6 \%{ }^{26}$

\section{Normal subjects: MoCA-test performance in $\varepsilon 4$ allele carriers and noncarriers and their different risk factors}

In normal subjects, both carriers and noncarriers, a lower MoCA-test score was found in those who had equal or less than five years of schooling compared to subjects with more than 5 years of schooling, carriers: median 24.5 [IQR: 21.5- 27] versus 26 [IQR: 25-28], $\mathrm{p}=0.010$, Cliff's delta $=-0.30$ (small); noncarriers: median 24 [IQR: 20-26] versus 27 [IQR: 25-28], $\mathrm{p}=0.000$, Cliff's delta $=-0.45$ (medium).

The same was observed in subjects with equal or less than 10 years of schooling compared to those who had 11 or more years of schooling, carriers: median 25 [IQR: 22-28] versus 26 [IQR: 25-28], $\mathrm{p}=0,048$, Cliff's delta $=0.21$ (small); and noncarriers: 25 [IQR: 22-27]) versus 27 [IQR: 25-28], $\mathrm{p}=0.000$, Cliff's delta $=0.43$ (medium).

Likewise, subjects with 70 years of age or older had a lower MoCA-test score compared to younger elderly population, carriers: median 24.5 [IQR: 21.5-27 versus 26 [IQR: $25-28$ ], $\mathrm{p}=0.007$, Cliff's delta $=0.35$ (medium); noncarriers: median 24 [IQR: 20-26]) versus 27 [IQR: 25-28], $\mathrm{p}=0.043$, Cliff's delta $=0.12$ (negligible).

There were no differences for $\varepsilon 4$ allele carriers and noncarriers in the MoCA-test score, between subjects with or without other risk factors (DM, HBP, overweight, or dyslipidemia) (Table 2 and Figure 1).

\section{Subjects with MCI: MoCA-test performance in $\varepsilon 4$ carriers and noncarriers and their different risk factors}

In subjects with $\mathrm{MCI}$, the results were similar to those observed in individuals with normal cognition; a lower MoCA-test score was found in those who had equal or less than five years of schooling compared to subjects with more than 5 years of schooling also in both $\varepsilon 4$ allele carriers and noncarriers. In the MoCA-test for a schooling of five years or less, carriers: median: 19 [IQR: 16-21] versus 22 [IQR: 20-23.5], $\mathrm{p}=0.000$, Cliff's delta $=-0.50$ (large); noncarriers: median 20 [IQR: 16-22]) versus 21 [IQR: 19-23], $\mathrm{p}=0.000$, Cliff's delta $=-0.29$ (small). The same was observed in subjects with equal or less than 10 years of schooling compared to those who had 11 or more years of schooling, carriers: median: 20 [IQR: 18-22] versus 23 [IQR: 22-24], $\mathrm{p}=0.000$, Cliff's delta $=0.52$ (large); noncarriers: median 20 [IQR:
17-22]) versus 22 [IQR: 19-24], $\mathrm{p}=0.000$, Cliff's delta $=0.32$ (small).

Similar results were observed in subjects of 70 years of age or older who had a lower MoCA-test score compared to younger elderly population, carriers: median: 20 [IQR: 18-22] versus 23 [IQR: 22-24], $\mathrm{p}=0.011$, Cliff's delta $=0.30$ (small); noncarriers: median: 20 [IQR: 17-22]) versus 21 [IQR: 19-23], $\mathrm{p}=0.000$, Cliff's delta $=0.23$ (small).

However, a lower score in MoCA test was observed in subjects with high blood pressure, noncarriers with the factor compared to noncarriers without factor (although the median was similar, the Mann-Whitney U test detected differences: median: 20 [IQR: 17-22] versus 20 [IQR: 18-23], $\mathrm{p}=0.022$, Cliff's delta $=0.14$ (negligible).

For the other risk factors, being a $\varepsilon 4$ allele carrier or not and being diabetic, overweight, or having dyslipidemia was not related to the performance in the MoCA-test, in subjects with MCI (Table 3 and Figure 1).

\section{Subjects with dementia: MoCA-test performance in $\varepsilon 4$ carriers and noncarriers and their different risk factors}

For patients with dementia, a lower MoCA-test score was observed, regardless if they were $\varepsilon 4$ allele carriers or not in those who had HBP compared with subjects without this risk factor, carriers: median 13 [IQR: 1215] versus 15 [IQR: $14-17$ ], $\mathrm{p}=0.043$, Cliff's delta $=0.30$ (small); noncarriers: median 12.5 [IQR: 9.5-16] versus 14 [IQR: 12-16], p=0.032, Cliff's delta $=0.30$ (small) and in whom schooling was less than 5 years, carriers: median 14 [IQR: 12-15] versus 16.5 [IQR: 14.5-18.5], $\mathrm{p}=0.000$, Cliff's delta $=-0.57$ (large); non-carriers: median: 13 [IQR: 10-15] versus 15 [IQR: 13-17], $\mathrm{p}=0.000$, Cliff's delta $=-0.38$ (medium).

Although, there was a tendency to lower scores in diabetic $\varepsilon 4$ carriers compared with noncarriers, carriers: median 13 [IQR: 9-14] versus noncarriers 14 [IQR: 13-16]); however, this was not statistically significant $(\mathrm{p}=0.066)$.

In the same way, no statistically significant differences were observed between subjects with and without the other risk factors, both carriers and noncarriers (Table 4).

The multiple correspondence analyses for patients with cognitive impairment presented an adjusted inertia for the first four dimensions of 23.09, 12.76, 11.60, and $10.45 \%$, respectively. The first dimension explains $23.09 \%$ of the variability of the data and the categories are organized mainly along this axis. The best representation of the variables was achieved in the first two dimensions, reaching $35.84 \%$ inertia (Figure 2). 
Figure 2 shows that the presence or absence of $\varepsilon 4$ allele, does not discriminate special groups, as the two categories ( $\varepsilon 4$ carrier vs non-carrier) are very close to the origin, which is consistent with the previous analyzes; being an $\varepsilon 4$ carrier is not associated with the other variables considered, although special relationships are observed on the axes: on axis 1 the educational level, degree of cognitive impairment and age are represented; axis 2 represents the presence or absence of comorbidities such as dyslipidemia, HBP, DM and overweight.

Table 2. Comparison of the Montréal Cognitive Assessment Test, by risk factors, between participants without cognitive impairment (normal), carriers and non-carriers of the allele $\varepsilon 4$.

\begin{tabular}{|c|c|c|c|c|c|c|c|}
\hline \multirow[b]{2}{*}{ Risk factor } & & \multicolumn{2}{|c|}{ Non- $\varepsilon 4$ allele carrier } & \multirow[b]{2}{*}{$\mathrm{p}$-value } & \multicolumn{2}{|c|}{$\varepsilon 4$ allele carrier } & \multirow[b]{2}{*}{ p-value } \\
\hline & & $\begin{array}{l}\text { Without the } \\
\text { factor }\end{array}$ & With the factor & & $\begin{array}{l}\text { Without the } \\
\text { factor }\end{array}$ & With the factor & \\
\hline \multirow{4}{*}{ Diabetes } & $\mathrm{n}$ & 357 & 54 & \multirow{4}{*}{0.281} & 108 & 9 & \multirow{4}{*}{0.274} \\
\hline & Age & $65.1(7.7)$ & $66.1(7.6)$ & & $64.4(7.9)$ & $63.6(9.2)$ & \\
\hline & Schooling & $11(5-17)$ & $8.5(5-16)$ & & $11(5-16)$ & $14(8-16)$ & \\
\hline & MoCA & $26(24-28)$ & $26(24-28)$ & & $26(24-28)$ & 27 (26-28) & \\
\hline \multirow{4}{*}{ High blood pressure } & $n$ & 244 & 167 & \multirow{4}{*}{0.009} & 72 & 45 & \multirow{4}{*}{0.777} \\
\hline & Age & $64.3(7.5)$ & $66.6(7.7)$ & & $62.8(7.4)$ & $66.9(8.2)$ & \\
\hline & Schooling & $11(5.5-17)$ & $11(5-17)$ & & $13(7-17)$ & $8(5-12)$ & \\
\hline & MoCA & $26(25-28)$ & $26(23-27)$ & & $26(24-28)$ & $26(24-28)$ & \\
\hline \multirow{4}{*}{ Overweight } & $n$ & 181 & 230 & \multirow{4}{*}{0.120} & 47 & 70 & \multirow{4}{*}{0.862} \\
\hline & Age & $65.4(8.2)$ & $65.1(7.3)$ & & $64.8(7.1)$ & $64.1(8.5)$ & \\
\hline & Schooling & $13(8-17)$ & $11(5-16)$ & & $12(7-17)$ & $10(5-14)$ & \\
\hline & $\mathrm{MoCA}$ & $26(24-28)$ & $26(24-27)$ & & $26(24-28)$ & $26(24-27)$ & \\
\hline \multirow{4}{*}{ Dyslipidemia } & $n$ & 296 & 115 & \multirow{4}{*}{0.998} & 65 & 52 & \multirow{4}{*}{0.835} \\
\hline & Age & $65.3(7.8)$ & $65.1(7.4)$ & & $64.4(8.9)$ & $64.4(6.7)$ & \\
\hline & Schooling & $11(5-17)$ & $11(5-17)$ & & $11(6-16)$ & $10(5-16)$ & \\
\hline & MoCA & $26(24-28)$ & $26(24-27)$ & & $26(25-27)$ & $26(24-28)$ & \\
\hline \multirow{4}{*}{ Schooling $\leq 5$ years } & $\mathrm{n}$ & 296 & 115 & \multirow{4}{*}{0.000} & 85 & 32 & \multirow{4}{*}{0.010} \\
\hline & Age & $64.5(7.7)$ & $67.1(7.4)$ & & $63.9(7.5)$ & $65.5(9.2)$ & \\
\hline & Schooling & $15(11-17)$ & $5(2-5)$ & & $13(11-17)$ & $5(3-5)$ & \\
\hline & MoCA & 27 (25-28) & $24(20-26)^{\star}$ & & $26(25-28)$ & $24.5(21.5-27)^{\star}$ & \\
\hline \multirow{4}{*}{ Schooling $\leq 10$ years } & $\mathrm{n}$ & 241 & 170 & \multirow{4}{*}{0.000} & 64 & 53 & \multirow{4}{*}{0.048} \\
\hline & Age & $64.1(7.7)$ & $66.8(7.3)$ & & $62.6(7.7)$ & $66.5(7.7)$ & \\
\hline & Schooling & $16(12-17)$ & $5(3-7)$ & & $15(12.5-17)$ & $5(4-7)$ & \\
\hline & MoCA & 27 (25-28) & $25(22-27)^{\star}$ & & $26(25-28)$ & $25(22-28)^{\star}$ & \\
\hline \multirow{4}{*}{ Age $\geq 70$ years old } & $n$ & 293 & 118 & \multirow{4}{*}{0.043} & 94 & 23 & \multirow{4}{*}{0.007} \\
\hline & Age & $61.3(4.7)$ & $74.9(4.2)$ & & $61.4(5.4)$ & $76.4(4.5)$ & \\
\hline & Schooling & $11(6-17)$ & $9.5(5-16)$ & & $11(6417)$ & $8(4-12)$ & \\
\hline & MoCA & $26(25-28)$ & $26(23-27)^{\star}$ & & $26(25-28)$ & $24(22-26)^{\star}$ & \\
\hline
\end{tabular}

*Statistically significant difference in MoCA test between the group with risk factor and the group without the risk factor, according to the Mann-Whitney $U$ test $(p<0.05)$. 


\section{Analysis of the interaction between being a $\varepsilon 4$ allele carrier and risk factors}

After adjusting age, when evaluating the interaction between being $\varepsilon 4$ allele carrier and having some risk factors, it was observed that the decrease in the MoCA-test score in the three groups of patients (normal, $\mathrm{MCI}$, and dementia) was related to low schooling $(\leq 5$ years or $\leq 10$ years), regardless of the status of the $\varepsilon 4$ allele.

In addition, in patients with $\mathrm{MCI}$ a decrease of one point in the median MoCA test score was observed, in carrier subjects with high blood pressure versus noncarriers without high blood pressure.

Table 3. Comparison of Montréal Cognitive Assessment Test, by risk factors, between participants with mild cognitive impairment, carriers and non-carriers of the allele $\varepsilon 4$.

\begin{tabular}{|c|c|c|c|c|c|c|c|}
\hline \multirow[b]{2}{*}{ Risk factor } & & \multicolumn{2}{|c|}{ Non- $\varepsilon 4$ allele carrier } & \multirow[b]{2}{*}{$\mathrm{p}$-value } & \multicolumn{2}{|c|}{$\varepsilon 4$ allele carrier } & \multirow[b]{2}{*}{ p-value } \\
\hline & & $\begin{array}{c}\text { Without the } \\
\text { factor }\end{array}$ & With the factor & & $\begin{array}{l}\text { Without the } \\
\text { factor }\end{array}$ & With the factor & \\
\hline \multirow{4}{*}{ Diabetes } & $\mathrm{n}$ & 278 & 45 & \multirow{4}{*}{0.141} & 77 & 14 & \multirow{4}{*}{0.319} \\
\hline & Age & $69.3(7.8)$ & $69.1(8.9)$ & & $68.9(7.0)$ & $68.3(7.5)$ & \\
\hline & Schooling & $5(3-11)$ & $5(3-11)$ & & $7(3-11)$ & $8.5(5-12)$ & \\
\hline & MoCA & 20 (18-22) & 19 (17-22) & & $22(19-23)$ & $20.5(19-23)$ & \\
\hline \multirow{4}{*}{ High blood pressure } & $\mathrm{n}$ & 165 & 158 & \multirow{4}{*}{0.022} & 54 & 37 & \multirow{4}{*}{0.437} \\
\hline & Age & $68.4(8.7)$ & $70.3(7.2)$ & & $68.3(6.5)$ & $69.6(7.8)$ & \\
\hline & Schooling & $6(4-11)$ & $5(3-11)$ & & $7.5(5-11)$ & $7(3-11)$ & \\
\hline & MoCA & $20(18-23)$ & $20(17-22)^{*}$ & & $22(19-23)$ & $21(18-23)$ & \\
\hline \multirow{4}{*}{ Overweight } & $\mathrm{n}$ & 130 & 193 & \multirow{4}{*}{0.639} & 47 & 44 & \multirow{4}{*}{0.869} \\
\hline & Age & $70.6(8.5)$ & $68.4(7.6)$ & & $69.5(7.1)$ & $68.0(7.0)$ & \\
\hline & Schooling & $5.5(3-10)$ & $5(3-11)$ & & $8(3-12)$ & $6.5(3-11)$ & \\
\hline & MoCA & $20(17-22)$ & 20 (18-22) & & $22(18-23)$ & $21(19-23)$ & \\
\hline \multirow{4}{*}{ Dyslipidemia } & $\mathrm{n}$ & 208 & 115 & \multirow{4}{*}{0.179} & 53 & 38 & \multirow{4}{*}{0.150} \\
\hline & Age & $69.1(8.3)$ & $69.6(7.5)$ & & $68.5(7.1)$ & $69.3(7.0)$ & \\
\hline & Schooling & $5(4-11)$ & $5(3-11)$ & & $8(3-11)$ & $6.5(3-12)$ & \\
\hline & MoCA & $20.5(18-22)$ & 20 (17-22) & & $20(18-23)$ & $22(20-23)$ & \\
\hline \multirow{4}{*}{ Schooling $<=5$ years } & $\mathrm{n}$ & 151 & 172 & \multirow{4}{*}{0.000} & 52 & 39 & \multirow{4}{*}{0.000} \\
\hline & Age & $68.3(8.5)$ & $70.1(7.5)$ & & $66.7(6.5)$ & $71.6(6.8)$ & \\
\hline & Schooling & $11(8-14)$ & $3(2-5)$ & & $11(8-15.5)$ & $3(2-5)$ & \\
\hline & MoCA & 21 (19-23) & $20(16-22)^{\star}$ & & $22(20-23.5)$ & $19(16-21)^{\star}$ & \\
\hline \multirow{4}{*}{ Schooling $\leq 10$ years } & $\mathrm{n}$ & 89 & 234 & \multirow{4}{*}{0.000} & 32 & 59 & \multirow{4}{*}{0.000} \\
\hline & Age & $66.8(8.7)$ & $70.2(7.5)$ & & $66.8(6.9)$ & $69.9(6.9)$ & \\
\hline & Schooling & $13(11-17)$ & $5(3-6)$ & & $12.5(11-17)$ & $5(2-7)$ & \\
\hline & MoCA & $22(19-24)$ & $20(17-22)^{\star}$ & & $23(22-24)$ & $20(18-22)^{\star}$ & \\
\hline \multirow{4}{*}{ Age $\geq 70$ years old } & $\mathrm{n}$ & 155 & 168 & \multirow{4}{*}{0.000} & 51 & 40 & \multirow{4}{*}{0.011} \\
\hline & Age & $62.5(4.6)$ & $75.6(4.7)$ & & $63.8(4.2)$ & $75.2(4.4)$ & \\
\hline & Schooling & $5(3-11)$ & $5(3-9.5)$ & & $9(5-13)$ & $5(2-8)$ & \\
\hline & MoCA & $21(19-23)$ & $19(17-22)^{\star}$ & & $22(20-23)$ & $20(17-22)^{\star}$ & \\
\hline
\end{tabular}

*Statistically significant difference in MoCA test between the group with risk factor and the group without the risk factor, according to the Mann-Whitney $\mathrm{U}$ test $(\mathrm{p}<0.05)$. 
On the basis of the results described above, patients with dementia carrying $\varepsilon 4$ allele and without overweight showed a decrease of 2.58 points in the median of the MoCA-test score. In all comparisons that reached statistical significance, the greatest decreases in the MoCA-test score were observed in subjects with dementia (Table 5 and Figure 2).

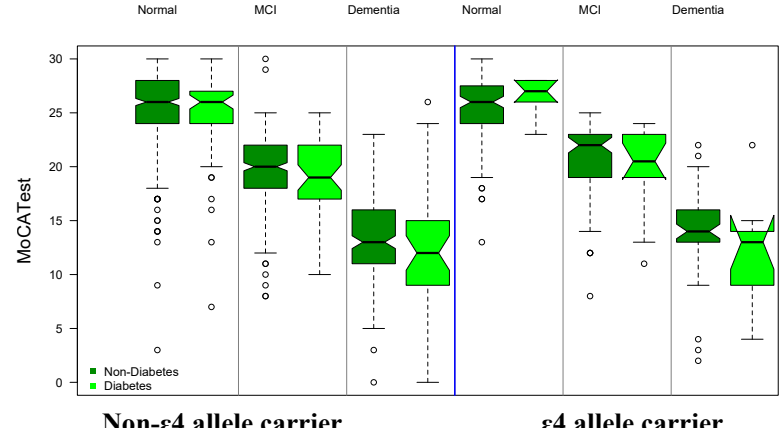

Non- $\varepsilon 4$ allele carrier

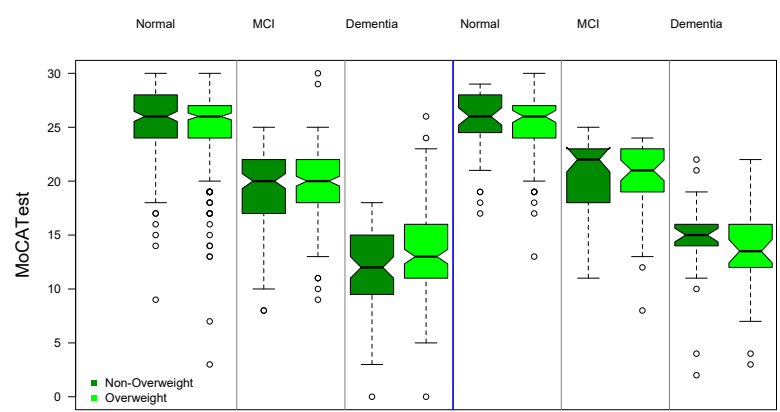

Non- $\varepsilon 4$ allele carrier

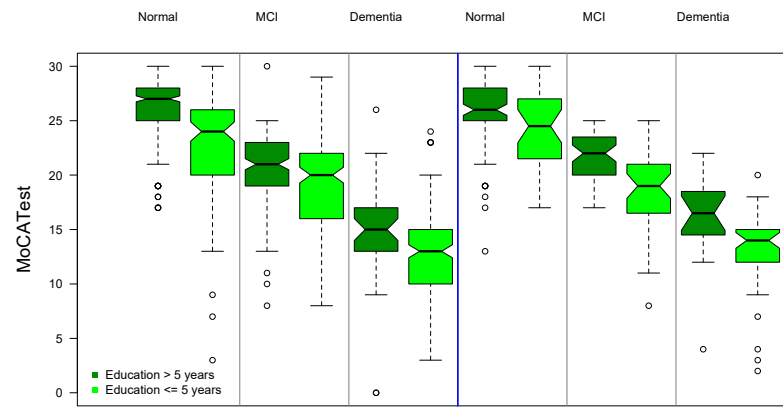

Non- $\varepsilon 4$ allele carrier $\varepsilon 4$ allele carrier

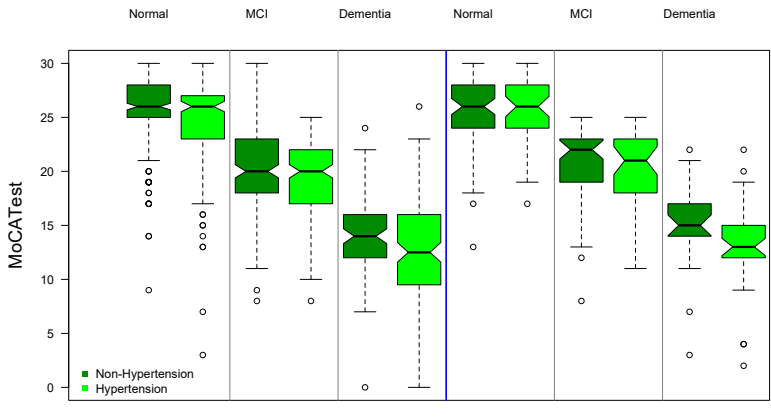

Non- $\varepsilon 4$ allele carrier

84 allele carrier

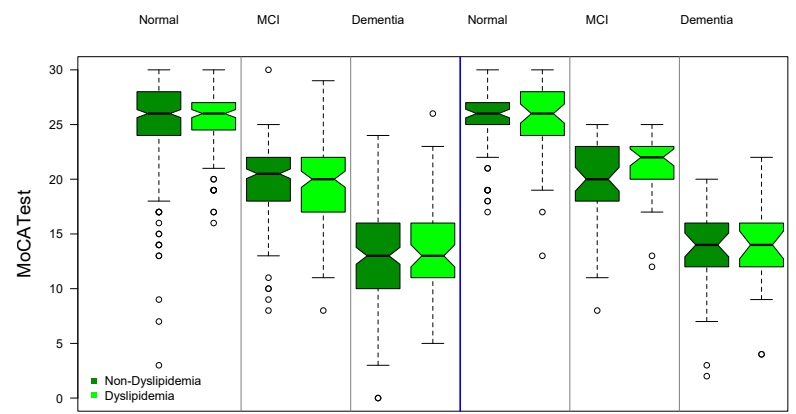

Non- $\varepsilon 4$ allele carrier

$\varepsilon 4$ allele carrier

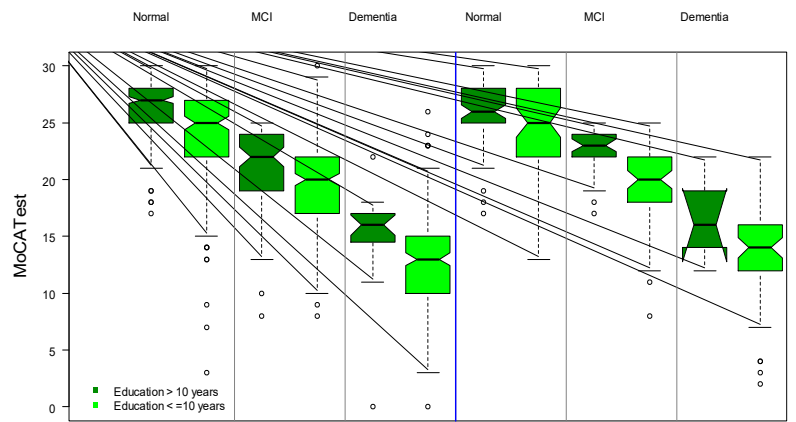

Non- $\varepsilon 4$ allele carrier

$\varepsilon 4$ allele carrier

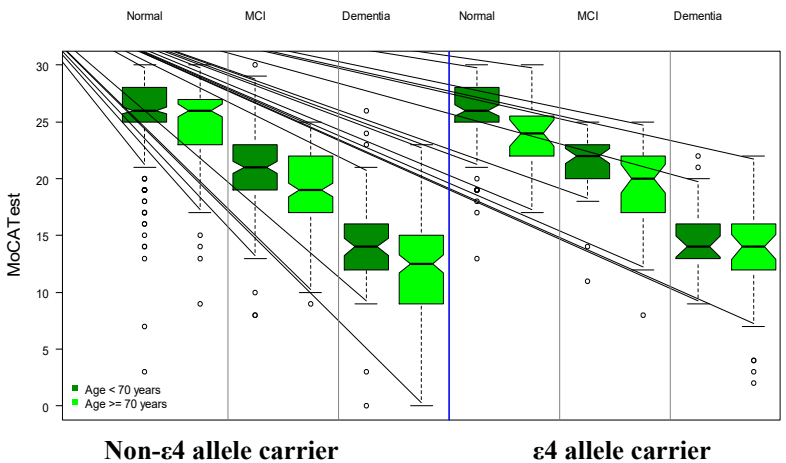

Figure 1. Performance in the Montréal Cognitive Assessment Test according to the carrier status or not of allele $\varepsilon 4$, cognitive status and the presence or absence of the risk factor. 


\section{DISCUSSION}

Being an $\varepsilon 4$ carrier has been recognized as the main genetic risk factor associated with the development of late-onset $\mathrm{AD} .^{8}$ The percentage distribution of the isoforms described in the literature for the alleles of the APOE gene is $79 \%$ for the $\varepsilon 3$ allele, $13.3 \%$ for the $\varepsilon 4$ allele, and $7.3 \%$ for the $\varepsilon 2$ allele. ${ }^{27,28}$ The genotype frequencies of the APOE gene in our sample studied were similar to those described in Colombian, Latin American, and world literature. ${ }^{26} \mathrm{~A}$ hazard ratio (HR) of 1.35 (95\% CI 1.00-1.83) has been reported between the presence of the $\varepsilon 4$ allele and the risk of $\mathrm{AD},{ }^{29}$ whereas in a previous study in Colombia, it has been observed that the relationship has an OR of 5.1. ${ }^{30}$

Table 4. Comparison of Montréal Cognitive Assessment test, by risk factors, between patients with dementia carriers and non-carriers of the allele $\varepsilon 4$.

\begin{tabular}{|c|c|c|c|c|c|c|c|}
\hline \multirow[b]{2}{*}{ Risk factor } & & \multicolumn{2}{|c|}{ Non- $\varepsilon 4$ allele carrier } & \multirow[b]{2}{*}{ p-value } & \multicolumn{2}{|c|}{$\varepsilon 4$ allele carrier } & \multirow[b]{2}{*}{ p-value } \\
\hline & & $\begin{array}{l}\text { Without the } \\
\text { factor }\end{array}$ & With the factor & & $\begin{array}{l}\text { Without the } \\
\text { factor }\end{array}$ & With the factor & \\
\hline \multirow{4}{*}{ Diabetes } & $\mathrm{n}$ & 178 & 35 & \multirow{4}{*}{0.215} & 49 & 12 & \multirow{4}{*}{0.066} \\
\hline & Age & $73.3(8.9)$ & $73.7(8.4)$ & & $70.6(7.5)$ & $75.5(7.9)$ & \\
\hline & Schooling & $3(2-5)$ & $4(1-5)$ & & $4.5(2-6)$ & $2(0-5)$ & \\
\hline & MoCA & $13(11-16)$ & $12(9-15)$ & & $14(13-16)$ & $13(9-14)^{*} 0.06$ & \\
\hline \multirow{4}{*}{ High blood pressure } & $\mathrm{n}$ & 85 & 128 & \multirow{4}{*}{0.032} & 24 & 35 & \multirow{4}{*}{0.043} \\
\hline & Age & $71.7(8.6)$ & $74.4(8.8)$ & & $70.6(8.3)$ & 71.8(7.6) & \\
\hline & Schooling & $4(2-5)$ & $3(1-5)$ & & $5(2.5-8.5)$ & $4(1-5)$ & \\
\hline & MoCA & $14(12-16)$ & $12.5(9.5-16)^{\star}$ & & $15(14-17)$ & $13(12-15)^{\star}$ & \\
\hline \multirow{4}{*}{ Overweight } & $\mathrm{n}$ & 76 & 137 & \multirow{4}{*}{0.038} & 25 & 34 & \multirow{4}{*}{0.111} \\
\hline & Age & $75(8.9)$ & $72.4(8.6)$ & & $71.7(8.6)$ & $71.1(7.3)$ & \\
\hline & Schooling & $4(2-5)$ & $3(1-5)$ & & $5(3-9)$ & $3(1-5)$ & \\
\hline & MoCA & $12(9.5-15)$ & $13(11-16)^{\star}$ & & $15(14-16)$ & $13.5(12-16)$ & \\
\hline \multirow{4}{*}{ Dyslipidemia } & $\mathrm{n}$ & 154 & 61 & \multirow{4}{*}{0.308} & 34 & 25 & \multirow{4}{*}{0.694} \\
\hline & Age & $73.9(8.7)$ & $71.8(8.8)$ & & $72.9(7.7)$ & $69.1(7.6)$ & \\
\hline & Schooling & $4(1.5-5)$ & $3(2-5)$ & & $4(2-6)$ & $4(2-5)$ & \\
\hline & MoCA & $13(10-16)$ & $13(11-16)$ & & $14(12-16)$ & $14(12-16)$ & \\
\hline \multirow{4}{*}{ Schooling $\leq 5$ years } & $\mathrm{n}$ & 39 & 174 & \multirow{4}{*}{0.000} & 16 & 43 & \multirow{4}{*}{0.000} \\
\hline & Age & $70.5(10.3)$ & $73.9(8.3)$ & & $72.3(6)$ & $70.9(8.4)$ & \\
\hline & Schooling & $9(7-13)$ & $3(1-5)$ & & $9(8-11)$ & $3(1-5)$ & \\
\hline & MoCA & $15(13-17)$ & $13(10-15)^{*}$ & & $16.5(14.5-18.5)$ & $14(12-15)^{\star}$ & \\
\hline \multirow{4}{*}{ Schooling $\leq 10$ years } & $\mathrm{n}$ & 19 & 194 & \multirow{4}{*}{0.000} & 6 & 53 & \multirow{4}{*}{0.106} \\
\hline & Age & $71.8(10.2)$ & $73.5(8.6)$ & & $72.8(2.8)$ & $71.3(8.1)$ & \\
\hline & Schooling & $13(11-17)$ & $3(1-5)$ & & $11(11-12)$ & $3(2-5)$ & \\
\hline & MoCA & $16(14-17)$ & $13(10-15)^{\star}$ & & $16(14-19)$ & $14(12-16)$ & \\
\hline \multirow{4}{*}{ Age $\geq 70$ years old } & $\mathrm{n}$ & 73 & 140 & \multirow{4}{*}{0.000} & 26 & 33 & \multirow{4}{*}{0.345} \\
\hline & Age & $63.5(4.3)$ & $78.5(5.6)$ & & $64.3(3.3)$ & $76.8(5.6)$ & \\
\hline & Schooling & $4(2-7)$ & $3(1-5)$ & & $3(2-5)$ & $5(2-8)$ & \\
\hline & MoCA & $14(12-16)$ & $12.5(9-15)^{*}$ & & $14(13-16)$ & $14(12-16)$ & \\
\hline
\end{tabular}

*Statistically significant difference in MoCA test between the group with risk factor and the group without the risk factor, according to the Mann-Whitney U test $(p<0.05)$. 
A relationship between age, sex, Apoc4, and cognitive impairment has been described. ${ }^{11}$ In this study, regardless of gender and being $\varepsilon 4$ carrier, those subjects over 70 years have a higher risk of cognitive impairment.

We also found a significant association between low schooling ( $\leq 5$ years)and a lower performance in the MoCA-test, regardless if they were or not $\varepsilon 4$ allele carriers and their cognitive status, results that are concordant with Borland et al., who found that low schooling ( $\leq 10$ years) was associated with significantly lower MoCA-test scores and concluded that schooling is a significant predictor for the MoCA-test score. ${ }^{31,32}$ Similar results were described by Conti et al., who after analyzing 225 healthy subjects with 5 or less years of schooling, observed that it influenced the final score of the test, especially in those subjects with only 1 year of schooling $(p<0.0001) .^{33}$
Accordingly, the difference between MoCA-test scores among subjects with low and high schooling in our study on average was 1.5 points, data that are consistent with those reported by Konstantopoulos et al., ${ }^{34}$ who find an average difference of 1.4 points comparing MoCA-test results for 1-9 years of schooling (low schooling), 10-12 years of schooling (high school) and above 13 years (bachelor or higher education).

In other studies, the interaction among cognitive impairment, Apo\&4, and schooling presents contradictory evidence; Seeman et al., ${ }^{35}$ Ishioka, ${ }^{36}$ and Vemuri et al. ${ }^{37}$ observed that the presence of at least one $\varepsilon 4$ allele reduces the protective effect of education on cognitive function, evidenced by a lower score of Short Portable Mental Status Questionnaire in subjects carrying $\varepsilon 4$ and with at least 9 years of schooling. On the contrary, Sando et al. found that a higher educational

\section{MCA factor map}

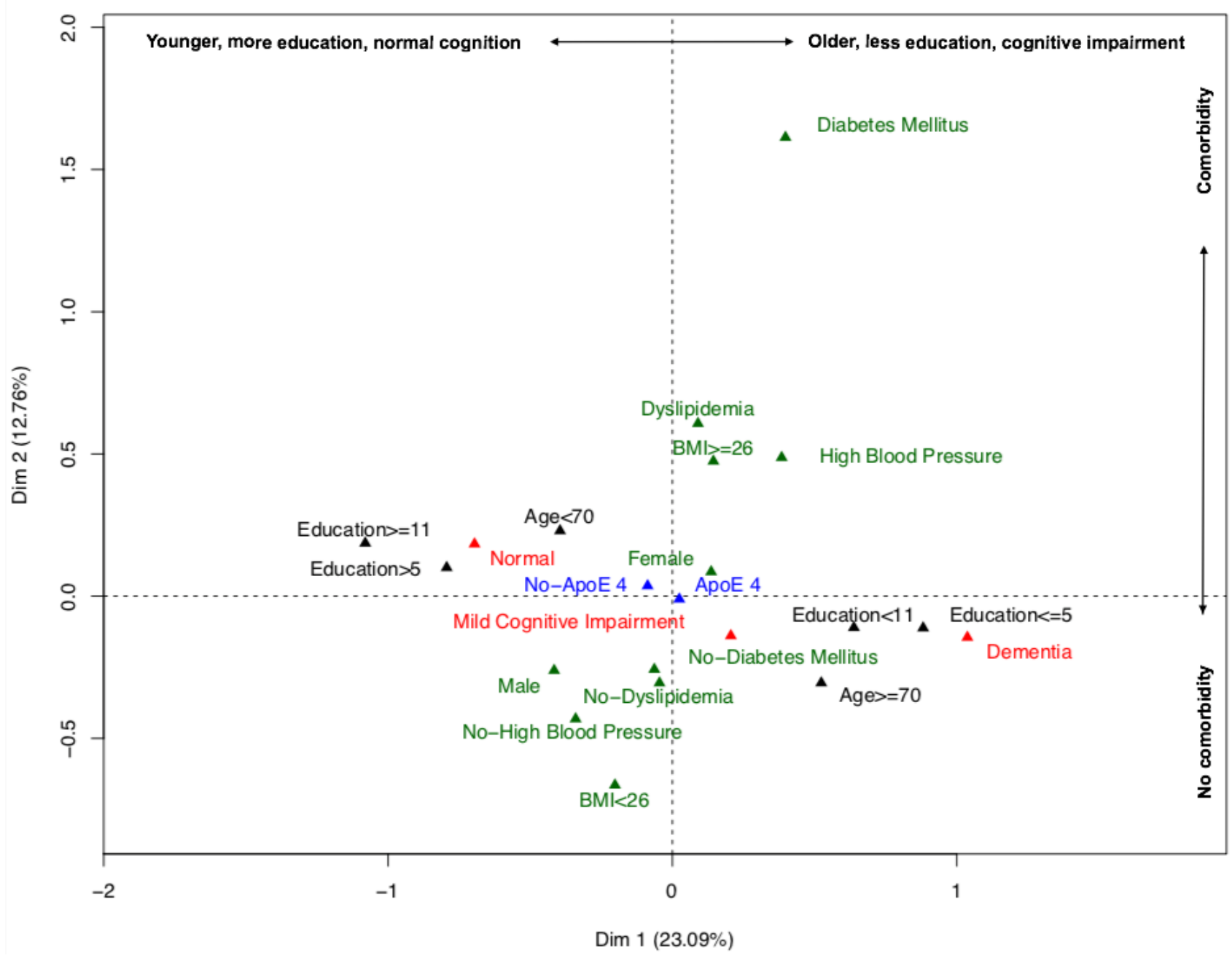

BMl: body mass index. The relationship between these variables is explained in two dimensions: vertical axis includes schooling, age, and cognitive status; horizontal axis includes cardiovascular factors. Figure 2. Factorial plane representing the relationship between risk factors, cognitive impairment, and condition of the allele $\varepsilon 4$. 
Table 5. Relationship between the Montréal Cognitive Assessment test and the age-adjusted interaction between risk factors and allelo $\varepsilon 4$.

\begin{tabular}{|c|c|c|c|c|c|c|}
\hline \multirow{2}{*}{ Factor } & \multicolumn{2}{|c|}{ Normal } & \multicolumn{2}{|c|}{ Mild cognitive impairment } & \multicolumn{2}{|c|}{ Dementia } \\
\hline & $\beta$ & p-value & $\beta$ & p-value & $\beta$ & p-value \\
\hline \multicolumn{7}{|l|}{ Diabetes } \\
\hline Non- $\varepsilon 4$ allele carrier, no diabetes & Ref. & & Ref. & & Ref. & \\
\hline Non- $\varepsilon 4$ allele carrier, with diabetes & -0.40 & 0.337 & -0.82 & 0.237 & -0.66 & 0.455 \\
\hline$\varepsilon 4$ allele carrier, no diabetes & -0.40 & 0.202 & 0.87 & 0.119 & 1 & 0.203 \\
\hline$\varepsilon 4$ allele carrier, with diabetes & 0.67 & 0.489 & 0.04 & 0.967 & -0.53 & 0.734 \\
\hline \multicolumn{7}{|l|}{ Hypertension } \\
\hline Non- $\varepsilon 4$ allele carrier, no hypertension & Ref. & & Ref. & & Ref. & \\
\hline Non- $\varepsilon 4$ allele carrier, with hypertension & -0.52 & 0.074 & -1 & 0.046 & -1.12 & 0.043 \\
\hline$\varepsilon 4$ allele carrier, no hypertension & -0.58 & 0.135 & 0.33 & 0.633 & 1.56 & 0.086 \\
\hline$\varepsilon 4$ allele carrier, with hypertension & -0.58 & 0.217 & -0.00 & 1.000 & 0 & 1.000 \\
\hline \multicolumn{7}{|l|}{ Overweight } \\
\hline Non- $\varepsilon 4$ allele carrier, unweight & Ref. & & Ref. & & Ref. & \\
\hline Non-£4 allele carrier, overweight & -0.50 & 0.091 & -0.09 & 0.858 & 0.76 & 0.224 \\
\hline$\varepsilon 4$ allele carrier, unweight & -0.81 & 0.096 & 1.00 & 0.186 & 2.58 & 0.011 \\
\hline$\varepsilon 4$ allele carrier, overweight & -0.43 & 0.297 & 0.63 & 0.413 & 1 & 0.270 \\
\hline \multicolumn{7}{|l|}{ Dyslipidemia } \\
\hline Non- $\varepsilon 4$ allele carrier, no dyslipidemia & Ref. & & Ref. & & Ref. & \\
\hline Non- $\varepsilon 4$ allele carrier, with dyslipidemia & -0.14 & 0.659 & -0.63 & 0.205 & 0 & 1.000 \\
\hline$\varepsilon 4$ allele carrier, no dyslipidemia & -0.21 & 0.595 & -0.27 & 0.681 & 1 & 0.281 \\
\hline ع4 allele carrier, with dyslipidemia & -0.78 & 0.076 & 1.27 & 0.095 & 1 & 0.349 \\
\hline \multicolumn{7}{|l|}{ Schooling $\leq 5$ years } \\
\hline Non- $\varepsilon 4$ allele carrier, $>5$ years & Ref. & & Ref. & & Ref. & \\
\hline Non- $\varepsilon 4$ allele carrier, $\leq 5$ years & -2.41 & 0.000 & -1.70 & 0.000 & -2.52 & 0.001 \\
\hline$\varepsilon 4$ allele carrier, $>5$ years & -0.52 & 0.166 & 0.80 & 0.204 & 0.76 & 0.550 \\
\hline$\varepsilon 4$ allele carrier, $\leq 5$ years & -2.41 & 0.000 & -2.1 & 0.003 & -1.61 & 0.089 \\
\hline \multicolumn{7}{|l|}{ Schooling $\leq 10$ years } \\
\hline Non- $\varepsilon 4$ allele carrier, $>10$ years & Ref. & & Ref. & & Ref. & \\
\hline Non- $\varepsilon 4$ allele carrier, $\leq 10$ years & -1.93 & 0.000 & -2 & 0.000 & -3 & 0.003 \\
\hline$\varepsilon 4$ allele carrier, $>10$ years & -0.75 & 0.128 & 0.72 & 0.407 & 0.71 & 0.971 \\
\hline$\varepsilon 4$ allele carrier, $\leq 10$ years & -1.68 & 0.002 & -2.09 & 0.004 & -2 & 0.078 \\
\hline \multicolumn{7}{|l|}{ Age $\geq 70$ years old } \\
\hline Non- $\varepsilon 4$ allele carrier, $<70$ years & Ref. & & Ref. & & Ref. & \\
\hline Non- $\varepsilon 4$ allele carrier, $\geq 70$ years & 0.42 & 0.377 & 0.09 & 0.912 & -2 & 0.003 \\
\hline$\varepsilon 4$ allele carrier, $<70$ years old & -0.07 & 0.826 & 1.09 & 0.143 & 0.00 & 1.000 \\
\hline$\varepsilon 4$ allele carrier, $\geq 70$ years old & -1.21 & 0.106 & 0.18 & 0.860 & 0.00 & 1.000 \\
\hline
\end{tabular}


level was related to a lower OR (participants with 10-18 years of education showed a lower OR purchased with subjects with 6-7 years of education); however, the protector effect of education on the onset of dementia wasn't modified by the presence of $\varepsilon 4$ alleles; ${ }^{38}$ These studies are in agreement with our results and with those of Sánchez et al., who failed to demonstrate a relationship between educational level, cognitive impairment (MCI or dementia) and being $\varepsilon 4$ carrier. ${ }^{39}$ Recent studies confirm the variability of this interaction. ${ }^{40}$

Other studies have described the relationship between the presence of the $\varepsilon 4$ allele, some cardio-metabolic factors, and the development of cognitive impairment, which suggests that the presence of this allele would modify the association between dementia and HBP. ${ }^{41-42}$ In our study we found that subjects with HBP had a lower performance in the MoCA test, regardless of whether they were $\varepsilon 4$ allele carriers or not; similar studies have been performed using the Mini-mental test (MMSE) and the MoCA test. ${ }^{43-45}$

When assessing whether the scores obtained in the MoCA test in subjects $\varepsilon 4$ carriers with HBP were different from those being HBP non- $\varepsilon 4$ carriers, our study found no differences. When analyzing the independent relationship of the MoCA test scores, Bangen et al. ${ }^{14}$ found that vascular risk factors, such as HBP, provide a higher risk of cognitive impairment and could be strengthened by the presence of the $\varepsilon 4$ allele. ${ }^{25}$ In addition, Weinstein et al. analyzed the relationship between $\varepsilon 4$ allele and HBP (measured within the Framingham scale and changes in the MoCA-test score); they found that high scores on this scale of cardiovascular risk factors were related to low performance on the cognitive scale, this relationship wasn't modified by the presence of the $\varepsilon 4$ allele, as we found in our study. ${ }^{46}$

On the contrary, our study showed a lower performance of the MoCA-test in subjects with dementia, $\varepsilon 4$ carriers diabetics compared to $\varepsilon 4$ carriers non-diabetic. The relationship among AD, APOE4, and DM was assessed by Haan et al., who described that the $\varepsilon 4 / \varepsilon 4$ genotype contributes synergistically with type 2 diabetes (DM2) in the development of AD.$^{47}$ Similar data were described by Zhao et al. ${ }^{48}$ and Johnson et al., ${ }^{49}$ who reported that $\varepsilon 4$ allele carriers diabetic had a higher prevalence of $\mathrm{AD}$ compared with noncarriers $\varepsilon 4$ diabetics subjects ( 7.55 vs. $2.3 \%$ ), with a risk probability of 3,982 [95\%CI 1,418-11,184] of developing dementia in diabetic subjects and $\varepsilon 4$ carriers, however, additional studies are still required to demonstrate this relationship, as stated by Shinohara $\mathrm{M}$ et al in the most recent review of $2020 .^{50}$
Differences in cognitive scales between diabetic carriers and noncarriers were described by Palmer et al., who reported that $\varepsilon 4$ diabetic patients had lower scores on the MMSE test compared to noncarriers and non-diabetic subjects. ${ }^{51}$ On the contrary, Zhen et al. showed that subjects with at least one $\varepsilon 4$ allele and diabetics obtained lower scores on the MoCA test, independently of cognitive status. ${ }^{52}$

The presence of risk factors such as overweight or dyslipidemia were not related to the performance in the MoCA test, in $\varepsilon 4$ allele carriers and noncarriers. The relationship of overweight, poor performance on cognitive tests, and the presence of $\varepsilon 4$ allele have been poorly documented and its results are contradictory. In this regard, Blautzik et al. ${ }^{53}$ observed that on $\varepsilon 4$ carriers, the BMI had an inverse relationship with cognitive impairment ( $\beta=-0.209, p=0.05)$, higher BMI showed lower scores on cognitive tests; whereas Rajan et al. documented that $\varepsilon 4$ carriers, who were overweight, had a lower cognitive impairment when compared to overweight and noncarrier subject. ${ }^{54}$ Recent studies of this same group of subjects showed similar results to those of Blautzik et al., ${ }^{53}$ where the subjects who acquired dementia over time, had normal or low BMI suggesting that low weight was a more important risk factor than overweight. ${ }^{55-57}$

Regarding the relationship among cognition, dyslipidemia, and APOع4, Reitz et al., Hayden et al., ${ }^{59}$ and Wei et al. ${ }^{60}$ described an association among lipid metabolism, $\mathrm{AD}$, and $\varepsilon 4$ allele, but the mechanisms still require further research and larger sample sizes. ${ }^{58-60}$

Study limitations: $\varepsilon 4$ carrier population was smaller than the non- $\varepsilon 4$ carrier in most of the different risk factor groups, a fact that could have interfered in the association forces between the different risk factors and the presence of $\varepsilon 4$ allele.

We found that subjects with low schooling $(\leq 5$ years or $\leq 10$ years) and subjects with HBP had lower performances in the MoCA-test scores, regardless of being $\varepsilon 4$ carrier or not, and presenting or not cognitive impairment.

Being an $\varepsilon 4$ carrier and diabetic showed a tendency to present the lowest scores in the MoCA-test only in subjects with dementia as compared to diabetic subjects with dementia noncarriers $\varepsilon 4$.

A future study with a larger cohort and a longer longitudinal follow-up time could show us a greater effect of apoe 4 with risk factors on cognitive decline.

Extensive continuing education programs, in all age groups of our society, with a better control of risk factors and promotion of healthy lifestyles, are the best options currently available to reduce the onset and progression of cognitive decline. 


\section{ACKNOWLEDGMENTS}

We express our gratitude to the adults who participated and their companions; to Hernández Gualberto for his technical work in genetics; to the nursing professors Yolanda Muñoz and Jose M Diaz in the sampling; and the support in evaluations to the students of the neuroscience research seedbed Ánzola Katherine, Mejía Juan, and Ovalle Alejandra; to the residents of family medicine from the FUCS University; and to the psychology student group of the Universidad El Bosque.

Authors' contributions. OLP, AMS, CM, and AL were involved in project design. OLP, AMS, IC, CP, FS, CM, CR, LDG, LT, and DM were involved in data analysis. OLP, IC, AMS, CM, AL, LT, FS, and CP were involved in writing of the manuscript.

\section{REFERENCES}

1. Garre-Olmo J. Epidemiology of Alzheimer's disease and other dementias. Rev Neurol. 2018;66(11):377-86. https://doi.org/10.33588/ rn.6611.2017519

2. Cummings JL, Tong G, Ballard C. Treatment combinations for Alzheimer's disease: current and future pharmacotherapy options. J Alzheimers Dis. 2019:67(3):779-94. https://doi.org/10.3233/JAD-180766

3. Tisher A, Salardini A. A comprehensive update on treatment of dementia. Semin Neurol. 2019;39(2):167-78. https://doi.org/10.1055/s-0039-1683408

4. Wagner M, Helmer C, Tzourio C, Berr C, Proust-Lima C, Samieri C. Evaluation of the concurrent trajectories of cardiometabolic risk factors in the 14 years before dementia. JAMA Psychiatry. 2018;75(10):1033-42. https://doi.org/10.1001/jamapsychiatry.2018.2004.

5. Loeffler DA. Modifiable, non-modifiable, and clinical factors associated with progression of Alzheimer's disease. J Alzheimers Dis. 2021;80(1):1-27. https://doi.org/10.3233/JAD-201182

6. Rochoy M, Rivas V, Chazard E, Decarpentry E, Saudemont G, Hazard PA, et al. Factors Associated with Alzheimer's disease: an overview of reviews. J Prev Alzheimers Dis. 2019;6(2):121-34. https://doi.org/10.14283/ jpad.2019.7

7. Norton S, Matthews FE, Barnes DE, Yaffe K, Brayne C. Potential for primary prevention of Alzheimer's disease: an analysis of population-based data. Lancet Neurol. 2014;13(8):788-9. https://doi.org/10.1016/ S1474-4422(14)70136-X

8. Broce IJ, Tan CH, Fan CC, Jansen I, Savage JE, Witoelar A, et al. Dissecting the genetic relationship between cardiovascular risk factors and Alzheimer's disease. Acta Neuropathol. 2019;137(2):209-26. https://doi. org/10.1007/s00401-018-1928-6

9. Pedraza OL, Perilla HJ, Cruz A, Botero JA, Montalvo MC, Salazar AM, et al. Cardiovascular and metabolic risk factors, for cognitive impairment in adults from Bogotá. Acta Neurol Colomb. 2016;32(2):91-9.

10. Wang Z, Meng L, Shen L, Ji HF. Impact of modifiable risk factors on Alzheimer's disease: a two-sample Mendelian randomization study. Neurobiol Aging. 2020;91:167.e11-167.e19. https://doi.org/10.1016/j. neurobiolaging.2020.02.018

11. Riedel BC, Thompson PM, Brinton RD. Age, APOE and sex: triad of risk of Alzheimer's disease. J Steroid Biochem Mol Biol. 2016;160:134-47. https://doi.org/10.1016/j.jsbmb.2016.03.012

12. Santos CY, Snyder PJ, Wu WC, Zhang M, Echeverria A, Alber J. Pathophysiologic relationship between Alzheimer's disease, cerebrovascular disease, and cardiovascular risk: A review and synthesis. Alzheimers Dement (Amst). 2017;9(7):69-87. https://doi.org/10.1016/j.dadm.2017.01.005

13. Ungar L, Altmann A, Greicius MD. Apolipoprotein E, gender, and Alzheimer's disease: an overlooked, but potent and promising interaction. Brain Imaging Behav. 2014;8(2):262-73. https://doi.org/10.1007/s11682-0139272-x

14. Bangen KJ, Beiser A, Delano-Wood L, Nation DA, Lamar M, Libon $\mathrm{DJ}$, et al. APOE genotype modifies the relationship between midlife vascular risk factors and later cognitive decline. J Stroke Cerebrovasc Dis. 2013;22(8):1361-9. https://doi.org/10.1016/j.jstrokecerebrovasdis.2013.03.013

15. Bangen KJ, Armstrong NM, Au R, Gross AL. Metabolic Syndrome and Cognitive Trajectories in the Framingham Offspring Study. J Alzheimers Dis. 2019;71(3):931-43. https://doi.org/10.3233/JAD-190261

16. Przybycien-Gaweda PM, Gwee X, Gao Q, Chua DQL, Fam J, Ng TP. Metabolic syndrome and cognition: follow-up study of Chinese over-55year-olds. Dement Geriatr Cogn Disord. 2020;49(2):129-37. https://doi. org/10.1159/000509124
17. Zou Z, Liu C, Che C, Huang H. Clinical genetics of Alzheimer's disease. Biomed Res Int. 2014;2014:291862. https://doi.org/10.1155/2014/291862

18. Yamazaki Y, Zhao N, Caulfield TR, Liu CC, Bu G. Apolipoprotein E and Alzheimer disease: pathobiology and targeting strategies. Nat Rev Neurol. 2019;15(9):501-18. https://doi.org/10.1038/s41582-019-0228-7

19. Qian J, Wolters FJ, Beiser A, Haan M, Ikram MA, Karlawish J, et al. APOE-related risk of mild cognitive impairment and dementia for prevention trials: An analysis of four cohorts. PLoS Med. 2017;14(3):e1002254. https:// doi.org/10.1371/journal.pmed.1002254

20. Kivipelto M, Mangialasche F, Ngandu T. Lifestyle interventions to prevent cognitive impairment, dementia and Alzheimer disease. Nat Rev Neurol. 2018;14(11):653-66. https://doi.org/10.1038/s41582-018-0070-3

21. Petersen RC. Mild cognitive impairment as a diagnostic entity. J Intern Med. 2004;256:183-94. https://doi.org/10.1111/j.1365-2796.2004.01388.x

22. American Psychiatric Association. Diagnostic and statistical manual of mental disorders: DSM-IV-TR. 5th ed. Madrid: Editorial Médica Panamericana; 2014.

23. Estrella-Castillo DF, Gómez-de-Regil L. Comparison of body mass index range criteria and their association with cognition, functioning and depression: a cross-sectional study in Mexican older adults. BMC Geriatr. 2019;19(1):339. https://doi.org/10.1186/s12877-019-1363-0

24. Yang YG, Kim JY, Park SJ, Kim SW, Jeon OH, Kim DS. Apolipoprotein E genotyping by multiplex tetra-primer amplification refractory mutation system PCR in single reaction tube. J Biotechnology. 2007;131(2):106-10. https://doi.org/10.1016/j.jbiotec.2007.06.001

25. Torchiano M. Effsize -A package for efficiente effect size computation. Zenodo; 2016. http://doi.org/10.5281/ZENODO.1480624

26. Rubio Gómez C, Gutiérrez LD, Pedraza OL, Torres Tobar L, Hernández Acevedo G, Suárez Camacho A, et al. Frecuencias genotípicas y alélicas de apolipoproteina e (APOE) en una muestra de adultos en Bogotá. Repert Med Cir. 2021;30(2):134-41. https://doi.org/10.31260/RepertMedCir.01217372.1008

27. Giau W, Bagyinszky E, An SS, Kim SY. Role of apolipoprotein E in neurodegenerative diseases. Neuropsychiatr Dis Treat. 2015;11:1723-37. https://doi.org/10.2147/NDT.S84266

28. Zhao N, Liu CC, Qiao W, Bu G. Apolipoprotein E, receptors, and modulation of Alzheimer's disease. Biol Psychiatry. 2018;83(4):347-57. https:// doi.org/10.1016/j.biopsych.2017.03.003

29. Hendrie HC, Murrell J, Baiyewu O, Lane KA, Purnell C, Ogunniyi A, et al. APOE $\varepsilon 4$ and the risk for Alzheimer disease and cognitive decline in African Americans and Yoruba. Int Psychogeriatr. 2014;26(6):977-85. https://doi. org/10.1017/S1041610214000167

30. Arango Viana JC, Valencia AV, Páez AL, Montoya Gómez N, Palacio C, Arbeláez MP. Prevalence of variants in the Apolipoprotein E (APOE) gene in a general population of adults from an urban area of Medellin (Antioquia). Rev Colomb Psiquiatr. 2014;43(2):80-6. https://doi.org/10.1016/j.rcp.2013.11.012

31. Borland E, Nägga K, Nilsson PM, Minthon L, Nilsson ED, Palmqvist S. The Montreal Cognitive Assessment: Normative Data from a Large Swedish Population-BasedCohort. J Alzheimers Dis. 2017;59(3):893-901. https:// doi.org/10.3233/JAD-170203

32. Cesar KG, Yassuda MS, Porto FH, Brucki SM, Nitrini R. MoCA Test: normative and diagnostic accuracy data for seniors with heterogeneous educational levels in Brazil. Arq Neuro-Psiquiatr. 2019;77(11):775-81. https://doi.org/10.1590/0004-282X20190130

33. Conti S, Bonazzi S, Laiacona M, Masina M, Coralli MV. Montreal Cognitive Assessment (MoCA)-Italian version: regression-based norms and equivalent scores. Neurol Sci. 2015;36(2):209-14. https://doi.org/10.1007/ s10072-014-1921-3 
34. Konstantopoulos K, Vogazianos P, Doskas T. Normative Data of the Montreal Cognitive Assessment in the Greek population and parkinsonian dementia. Arch Clin Neuropsychol. 2016;31(3):246-53. https://doi. org/10.1093/arclin/acw002

35. Seeman TE, Huang MH, Bretsky P, Crimmins E, Launer L, Guralnik JM. Education and APOE- $\varepsilon 4$ in longitudinal cognitive decline: Mac Arthur studies of successful aging. J Gerontol B Psychol Sci Soc Sci. 2005;60(2):7483. https://doi.org/10.1093/geronb/60.2.p74

36. Ishioka YL, Gondo Y, Fuku N, Inagaki H, Masui Y, Takayama M, et al. Effects of the APOE $\varepsilon 4$ allele and education on cognitive function in Japanese centenarians. Age (Dordr). 2016;38(5-6):495-503. https://doi. org/10.1007/s11357-016-9944-8

37. Vemuri P, Lesnick TG, Przybelski SA, Knopman DS, Machulda M, Lowe $\mathrm{VJ}$, et al. Effect of intellectual enrichment on AD biomarker trajectories: Longitudinal imaging study. Neurology. 2016;22;86(12):1128-35. https:// doi.org/10.1212/WNL.0000000000002490

38. Sando SB, Melquist S, Cannon A, Hutton M, Sletvold O, Saltvedt I, et al. Risk-reducing effect of education in Alzheimer's disease. Int J Geriatr Psychiatry. 2008;23(11):1156-62. https://doi.org/10.1002/gps.2043

39. Sánchez Contreras M, Moreno Gómez G, García Ortiz L. Deterioro cognitivo, nivel educativo y ocupación en una población de una clínica de memoria. Rev Colomb Psiquiatr. 2010;39:347-61. https://doi.org/10.1016/ S0034-7450(14)60255-9

40. Kang DW, Wang SM, Na HR, Lee CU, Baek IH, Lim HK. Differential effects of the interaction between the education and APOE $\varepsilon 4$ allele on amyloid-beta retention and memory performances in cognitively normal older adults and Alzheimer's disease patients. Curr Alzheimer Res. 2020;17(11):102332. https://doi.org/10.2174/1567205017666201229113416

41. Santos CY, Snyder PJ, Wu WC, Zhang M, Echeverria A, Alber J. Pathophysiologic relationship between Alzheimer's disease, cerebrovascular disease, and cardiovascular risk: A review and synthesis. Alzheimers Dement (Amst). 2017;9(7):69-87. https://doi.org/10.1016/j.dadm.2017.01.005

42. Viticchi G, Falsetti L, Buratti L, Sajeva G, Luzzi S, Bartolini M, et al. Framingham risk score and the risk of progression from mild cognitive impairment to dementia. J Alzheimers Dis. 2017;59(1):67-75. https://doi.org/10.3233/JAD-170160

43. Obisesan TO, Obisesan OA, Martins S, Alamgir L, Bond V, Maxwell C, et al. High blood pressure, hypertension, and high pulse pressure are associated with poorer cognitive function in persons aged 60 and older: the Third National Health and Nutrition Examination Survey. J Am Geriatr Soc. 2008;56(3):501-9. https://doi.org/10.1111/j.1532-5415.2007.01592.x

44. Sun D, Thomas EA, Launer LJ, Sidney S, Yaffe K, Fornage M. Association of blood pressure with cognitive function at midlife: a Mendelian randomization study. BMC Med Genomics. 2020;13(1):121. https://doi. org/10.1186/s12920-020-00769-y

45. Muela HC, Costa-Hong VA, Yassuda MS, Moraes NC, Memória CM, Machado MF et al. Hypertension severity is associated with impaired cognitive performance. J Am Heart Assoc. 2017;6(1):e004579. https:// doi.org/10.1161/JAHA.116.004579

46. Weinstein G, Preis SR, Beiser AS, Au R, Kelly-Hayes M, Kase CS, et al. Cognitive performance after stroke - The Framingham Heart Study. Int J Stroke. 2014:9 Suppl A100(0 0):48-54. https://doi.org/10.1111/ijs.12275

47. Haan MN, Shemanski L, Jagust WJ, Manolio TA, Kuller L. The role of APOE epsilon4 in modulating effects of other risk factors for cognitive decline in elderly persons. JAMA. 1999;282(1):40-6. https://doi.org/10.1001/jama.282.1.40
48. Zhao Q, Xiong Y, Ding D, Guo Q, Hong Z. J. Synergistic effect between apolipoprotein $\mathrm{E} \varepsilon 4$ and diabetes mellitus for dementia: result from a population-based study in urban China. J Alzheimers Dis. 2012;32(4):1019-27. https://doi.org/10.3233/JAD-2012-120442

49. Johnson LA, Torres ER, Impey S, Stevens JF, Raber J. Apolipoprotein E4 and insulin resistance interact to impair cognition and alter the epigenome and metabolome. Sci Rep. 2017;8(7):43701. https://doi.org/10.1038/ srep43701

50. Shinohara M, Tashiro Y, Suzuki K, Fukumori A, Bu G, Sato N. Interaction between APOE genotype and diabetes in cognitive decline. Alzheimers Dement (Amst). 2020;12(1):e12006. https://doi.org/10.1002/ dad2.12006

51. Palmer Allred ND, Raffield LM, Hardy JC, Hsu FC, Divers J, Xu J, et al. APOE genotypes associate with cognitive performance but not cerebral structure: diabetes heart study MIND. Diabetes Care. 2016;39(12):222531. https://doi.org/10.2337/dc16-0843

52. Zhen J, Lin T, Huang $X$, Zhang $H$, Dong $S$, Wu $Y$, et al. Association of Apoe genetic polymorphism and type 2 diabetes with cognition in non-demented aging chinese adults: a community based cross-sectional study. Aging Dis. 2018;9(3):346-57. https://doi.org/10.14336/ AD.2017.0715

53. Blautzik J, Kotz S, Brendel M, Sauerbeck J, Vettermann F, Winter Y, et al. Alzheimer's disease neuroimaging initiative. relationship between body mass index, Apoe4 status, and PET-based amyloid and neurodegeneration markers in amyloid-positive subjects with normal cognition or mild cognitive impairment. J Alzheimers Dis. 2018;65(3):781-91. https://doi. org/10.3233/JAD-170064

54. Rajan KB, Skarupski KA, Rasmussen HE, Evans DA. Gene-environment interaction of body mass index and apolipoprotein $\mathrm{E} \varepsilon 4$ allele on cognitive decline. Alzheimer Dis Assoc Disord. 2014;28(2):134-40. https://doi. org/10.1097/WAD.0000000000000013

55. Sun Z, Wang ZT, Sun FR, Shen XN, Xu W, Ma YH, et al. Alzheimer's Disease Neuroimaging Initiative. Late-life obesity is a protective factor for prodromal Alzheimer's disease: a longitudinal study. Aging (Albany NY). 2020;12(2):2005-17. https://doi.org/10.18632/aging.102738

56. Gil L, Ruiz de Sánchez C, Gil F, Romero SJ, Pretelt Burgos F. Validation of the Montreal Cognitive Assessment (MoCA) in Spanish as a screening tool for mild cognitive impairment and mild dementia in patients over 65 years old in Bogotá, Colombia. Int J Geriatr Psychiatry. 2015;30(6):655-62. https://doi.org/10.1002/gps.4199

57. Pedraza OL, Salazar A, Sierra F, Soler D, Castro J, Castillo P, et al. Reliability, criterion and discriminant validity of the Montreal Cognitive Assessment Test (MoCA) in a group of adults from Bogotá. Acta Med Colomb. 2016;40:221-8

58. Reitz C. Dyslipidemia and the risk of Alzheimer's disease. Curr Atheroscler Rep. 2013;15(3):307. https://doi.org/10.1007/s11883-012-0307-3

59. Hayden KM, Gaussoin SA, Hunter JC, Manson JE, Sachs BC, Shadyab $\mathrm{AH}$, et al. Cognitive resilience among APOE $\varepsilon 4$ carriers in the oldest old. Int J Geriatr Psychiatry. 2019;34(12):1833-44. https://doi.org/10.1002/ gps.5199

60. Wei S, Gao L, Jiang Y, Shang S, Chen C, Dang L, Wang J, et al. The Apolipoprotein $\mathrm{E} \varepsilon 4$ Allele-dependent relationship between serum lipid levels and cognitive function: a population-based cross-sectional study. Front Aging Neurosci. 2020;12:44. https://doi.org/10.3389/fnagi.2020.00044 